А.Б. Скорик, С.П. Ярош, Д.О. Меленті

Харківський наџіональний університет Повітряних Сил ім. І. Кожедуба, Харків

\title{
ВПЛИВ РУЙНІВНИХ ТЕХНОЛОГІЙ НА РОЗВИТОК АРХІТЕКТУРИ C4ISR СИСТЕМ. КОНЦЕПТУАЛЬНІ ОСНОВИ ПОБУДОВИ АРХІТЕКТУРИ ДАТА-ЦЕНТРИЧНОЇ СИСТЕМИ-СИСТЕМ
}

У статті проаналізовані особливості операційної, системної та технічної архітектури систем C4ISR. Розглянуто модель інформачійного обміну C4ISR. Як руйнівні розглядаються наступні технологї та інновації: сервіс-орієнтована архітектура, системи зі штучним інтелектом, хмарні обчислення і інтернет військових пристроїв; онтологія IDEAS, розширення єдиного інформаційно-бойового простору на кіберпростір, тактичні і стратегічні хмари. Робиться висновок про виникнення нової точки біфуркації, вихід з якої пов'язаний з розвитком теорї дата-центричних операцій $і$ розробкою дата-центричних систем-систем. Розглянуто загальну концепцію архітектури дата-центричної системи-систем, запропонована ресурсна-потокова модель архітектури дата-центричних систем-систем.

Ключові слова: дата-центрична операція, дата-цеентрична система-систем, мережецентрична війна, 4D-екстенціоналізм, самосинхронізація, мережеємні системи, структура архітектури, C4ISR.

\section{Вступ}

Постановка проблеми. Складність проектованих систем досягла критичного рівня. Це відкрило нові можливості й разом з тим призвело до ускладнення проблем для організацій, які створюють і використовують такі системи. Звичний структурний підхід до опису систем, що використовують мережеві й дата-центричні технології, вже не є цілком застосовуваним. Фундаментальні концепції систем стають все більше "нефізичними" і все більше віддаляються від того, що традиційно називають “структурою”. У класичному розумінні структура зазвичай співвідноситься 3 компонентами і організацією фізично ідентифікованих речей, таких як апаратні або програмні об'єкти, модулі. Але, наприклад, фундаментальна об'єднуюча організація мережевих структур - це не їх фізична структура і не структура програмного забезпечення. Обидві досить мінливі. Швидше стійкими, організуючими елементами мереж є протоколи, ключові концепції маршрутизації, які значною мірою визначають можливі мережеві структури, обмеження на можливі сервіси [1-3].

Підвищення складності і взаємозалежності систем, розвиток систем-систем (system of systems, $\mathrm{SoS}$ ) і сімейств систем (family of systems, FoS), ix структурна мінливість викликали значне зростання ролі архітектурних підходів при проектуванні озброєння [1]. Використання архітектурних підходів при створенні перспективних зразків ОВТ, особливо таких складних, як дата-центричні системи-систем, розглядається як одне 3 найбільш перспективних. Разом $з$ тим, науково-методичний апарат теорії датацентричних операцій знаходиться у фазі становлення і питання розробки концепції побудови архітектури дата-центричних систем-систем OBT (Data-Centric Weapon System of Systems - DWSoS, або DCWсистеми) потребують розвитку.

Аналіз останніх досліджень і публікацій. Питання використання архітектурних підходів при проектуванні систем-систем, розробки комерційних і військових структур архітектури розглянуто в роботах $[1-3 ; 9-10 ; 13 ; 15-17 ; 19 ; 21]$. Системноконцептуальні основи теорії дата-центричних операцій розглянуто у роботі [1]. Питання розбудови системи-систем і використання новітніх технологій у військовій справі розглянуто в [4; 6-8; 11-12; 14; $18 ; 20 ; 22-25]$.

Мета роботи. Метою статті $є$ подальший розвиток теорії дата-центричних операцій на основі аналізу еволюційного розвитку архітектури систем C4ISR i розробки концептуальних основ побудови apхітектури дата-центричних систем-систем.

\section{Виклад основного матеріалу}

\section{Аналіз особливостей архітектури C4ISR систем.}

Технічне втілення концепції мережецентричних війн шукалося в галузі розробки нового класу System of Systems - C4ISR. Початок зародження C4ISR пов'язують зі статтею адмірала William Owens, опублікованої Institute for National Security Studies [21], де було відмічено, що революція у військовій справі пов'язана з синергією трьох основних категорій:

- розвідка, спостереження i рекогносцировка (Intelligence, surveillance, and reconnaissance, ISR), 
включає у себе сенсорні та комунікаційні технології, що пов'язані зі збором розвідданих, спостереженням і рекогносцировкою, а також нові засоби, за допомогою яких ми можемо стежити за тим, що роблять наші власні сили;

- удосконалене C4I (command, control, communications, computer applications) командування, управління, зв'язок, комп'ютерні технології й обробка розвідданих - область, у якій сенсорна поінформованість перетворюється в домінуюче розуміння бойового простору й подальше перетворення цього розуміння в бойові завдання бою та операції, призначені для трансформації, управління й домінування в бойовому просторі;

- високоточна зброя (Precision force, PF). Широка концепція, в якій знання бойового простору та бойові розпорядження, що отримані у перших двох областях, втілюються у дію і результати.

До розробки структури архітектури (architecture framework, AF) C4ISR в MO США існували різні погляди на архітектуру. Ці погляди включали функціональні, операційні, інформаційні, фізичні, системні та технічні аспекти [9]. Була визнана необхідність загального підходу до розробки та представлення архітектур і виділені три основні архітектури: операційна, системна і технічна.

Структура архітектури C4ISR $\epsilon$ продукторієнтованою (product-centric). Розроблені в процесі побудови архітектури різного роду елементи опису архітектури (графічні, текстові, табличні) об'єднані терміном “продукти архітектури”, серед яких можна виділити основні (essential) продукти, що декларують єдині підходи (методологію) до проектування різних систем зброї й продукти підтримки (supporting) архітектури C4ISR - архітектурні рішення, обумовлені спеціалізацією систем зброї. У першій верciï C4ISR терміни “архітектура” й “архітектурний опис" часто використовувалися для опису тих самих сутностей. Чіткий поділ на архітектуру як абстрактне поняття й архітектурний опис як працюючий документ відбулося пізніше. На рис. 1 наведена структура архітектури C4ISR.

Операційна архітектура - це опис завдань (часто графічний), операційних елементів й інформаційних потоків, необхідних для виконання або підтримки функції ведення бойових дій, тобто описує операційні подання військового користувача й визначає тип інформації, частоту обміну й завдання, вирішення яких визначається формованими інформаційними потоками. Основна мета операційної архітектури: визначає види діяльності (activity) і вимоги до інформаційного обміну. Характеристики операційної архітектури:

- операційні архітектури починаються 3 доктрини і формулювання завдань, які, у свою чергу, визначають моделі діяльності;

- управляють архітектурою зв'язаних систем;
- опис діяльності не заснований на організаційних моделях або структурі сил;

- опис дій важливих для визначення моделі даних або вимог до інформаційного обміну;

- не мають залежати від системи.

Системна архітектура - це опис (у тому числі графічний) систем і взаємозв'язків, що забезпечують або підтримують функції ведення бойових дій. Системна архітектура визначає фізичне поєднання, місцеположення та ідентифікацію ключових вузлів, ланцюгів, мереж, платформ для бойових дій тощо, а також задає параметри продуктивності системи і компонентів. Архітектура системи побудована так, щоб задовольняти вимогам операційної архітектури відповідно до стандартів, що визначені в технічній архітектурі. Вона показує, як декілька систем в предметній області пов'язані і взаємодіють, і може описувати внутрішню структуру або операції конкретних систем у рамках архітектури. Основною метою системної архітектури є включення або автоматизація операційної діяльності за допомогою фізичних процесів. Характеристики системної архітектури:

- здійснюють зворотне відображення систем 3 їхніми відповідними платформами, функціями, характеристиками й елементами даних на операційну архітектуру;

- ідентифікують системні інтерфейси й визначають зв'язок між системами;

- визначають системні обмеження й межі поведінки системи;

- показують взаємозв'язок систем від датчика до вогневого засобу, стрільця/особи, що приймає рішення, через компоненти системи;

- залежать від технології, показують, як декілька систем у предметній області пов'язані між собою й взаємодіють, і можуть описувати внутрішні компоненти конкретних систем;

- не мають грунтуватися на поточних організаційних моделях, структурах сил або бойових статутах.

Системні архітектури зображують функціональні й фізичні автоматизовані системи, вузли, платформи, канали зв'язку й інші критичні елементи, які забезпечують підтримку вимог до обміну інформацією й завданням вогневих засобів, описаних в операційних архітектурах.

Різні атрибути систем, вузлів і необхідних інформаційних обмінів включені відповідно до мети конкретної архітектури.

Технічна архітектура - це мінімальний набір правил, що регулюють структуру, взаємодію й взаємозалежність частин або елементів, метою яких $є$ забезпечення того, щоб відповідна система задовольняла певному набору вимог. 


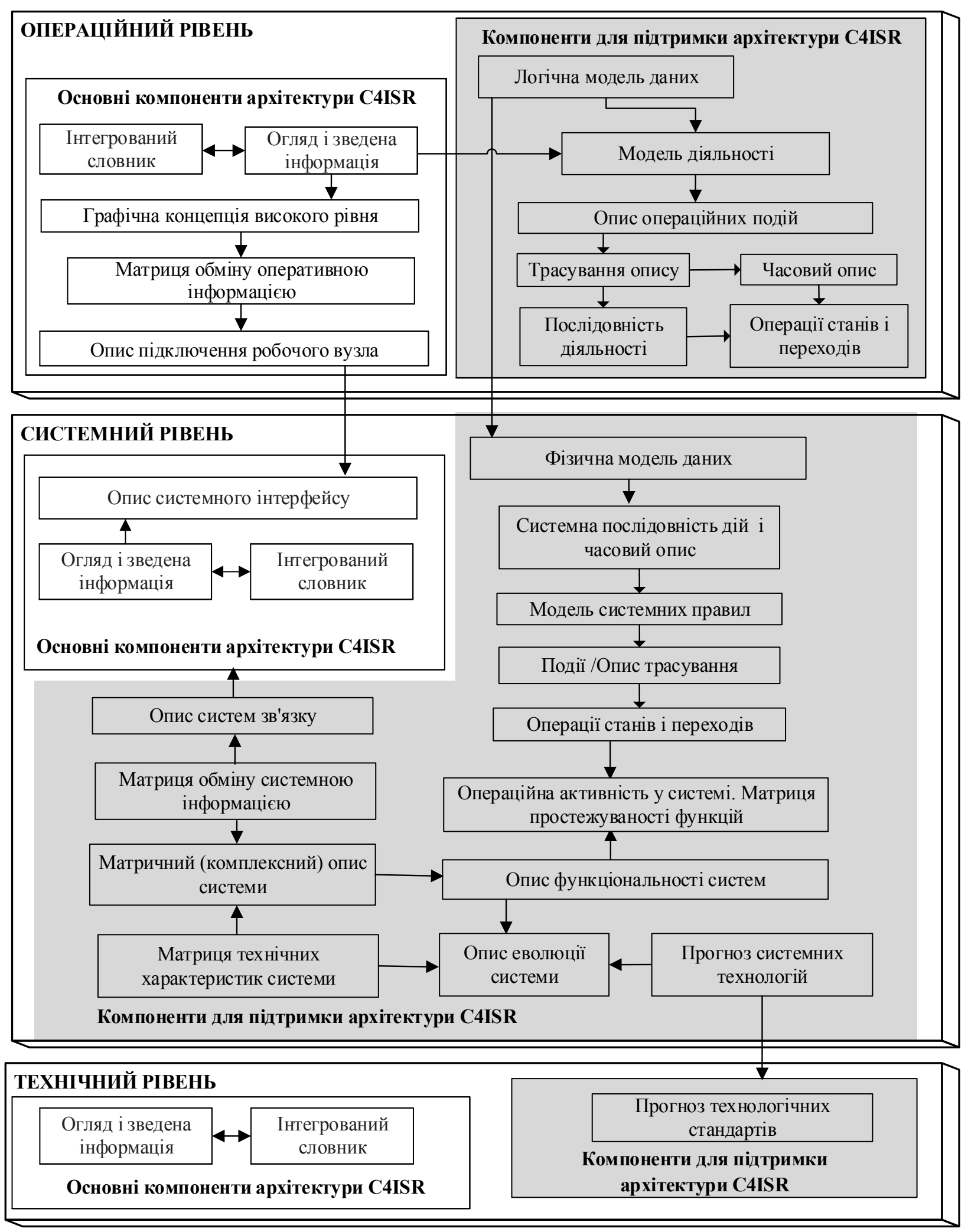

Рис. 1. Структура архітектури C4ISR

Джерело: розроблено авторами. 
Технічна архітектура визначає сервіси, інтерфейси, стандарти і їх взаємозв'язки. У ній містяться технічні рекомендації щодо впровадження систем, на яких засновані технічні специфікації, створюються загальні будівельні блоки й розробляються лінійки продуктів.

Основною метою технічної архітектури є визначення набору правил, що управляють впровадженням та експлуатацією систем.

Характеристики технічної архітектури:

- засновані на вимогах, визначених в операційній архітектурі, та аналізі можливих допоміжних технологій;

- інформаційні системи, парадигми обробки

бази даних і зв'язки визначені й сильно впливають на технічну архітектуру;

- ураховують вимоги до мультиплатформних і мережевих з'єднань між усіма системами, які виробляють, використовують або обмінюються інформацією в електронному вигляді;

- містять визначення й відповідні технічні критерії для можливостей системи, послуг та інтерфейсів;

- ураховують нові технології, стандарти, що розвиваються, й поступову відмову від старих технологій;
- правила технічної архітектури визначені в термінах непатентованих специфікацій і тому зменшують залежність від запатентованих технологій.

Ці визначення пояснюють відмінності між типами архітектур, підкреслюючи, що операційні архітектури представляють функціональні або логічні вимоги для підтримки завдань бойового застосування систем C4ISR, у той час як системна і технічна архітектури описують фізичні можливості й атрибути, які фактично задовольняють експлуатаційні потреби [9].

На рис. 2 надана модель інформаційного обміну систем, створюваних згідно вимог AF C4ISR V2.0 [17]. Модель інформаційного обміну C4ISR демонструє взаємні зв'язки й відносини між елементами даних, забезпечує зв'язування такої інформації (рис. 2): сценаріїв використання; операційних елементів, яким призначені місії; вузлів (нод), де розташовані операційні елементи; завдань й дій, які виконують операційні елементи; інформаційних потоків, необхідних для виконання завдань; систем, використовуваних для підтримки процесів виконання завдань та інформаційних потоків; системних атрибутів і параметрів продуктивності.

Вузол визначається як відправник, оброблювач i/або одержувач інформації або даних.

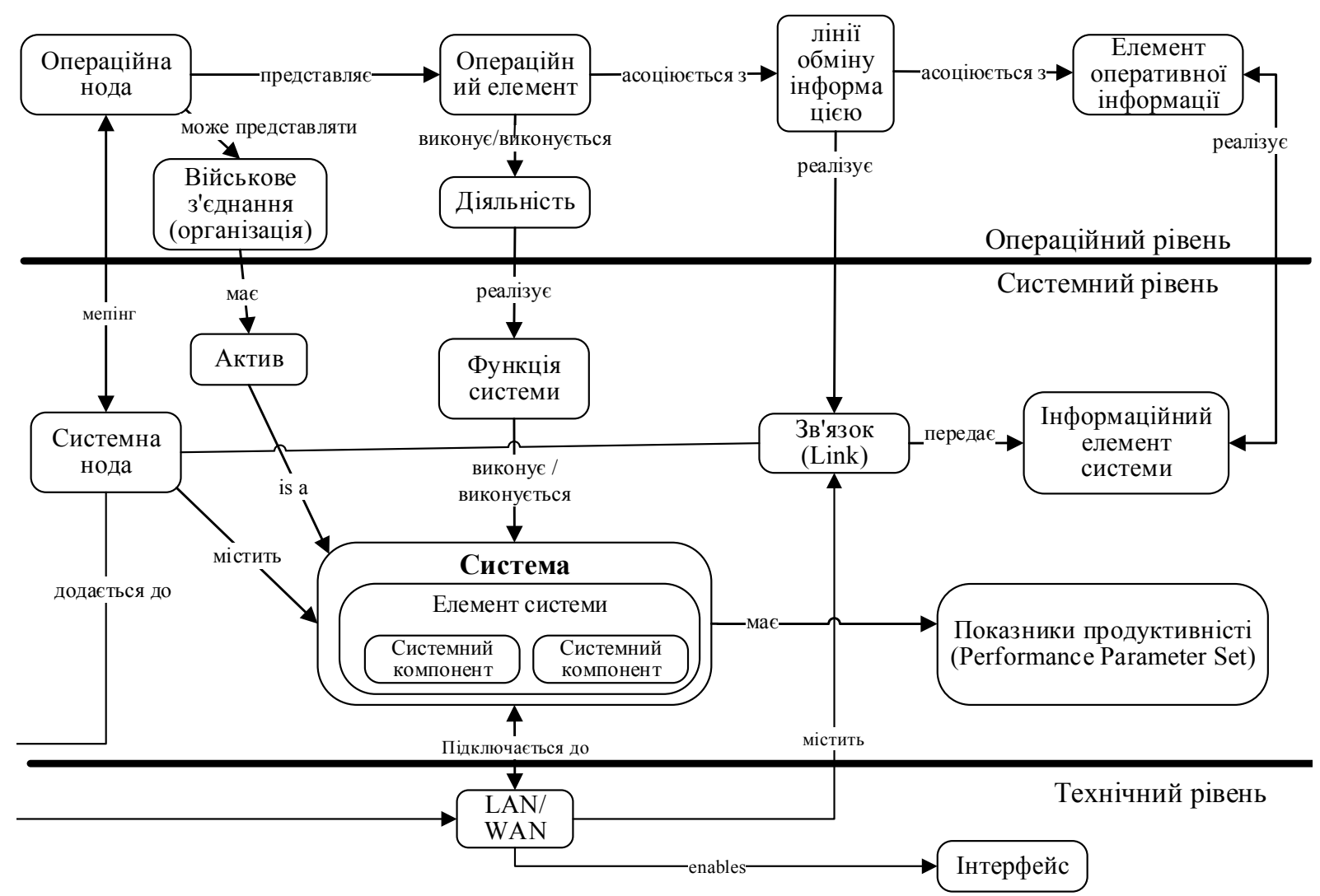

Рис. 2. Модель інформаційного обміну C4ISR

Джерело: розроблено авторами за даними [17]. 
У контексті операційних архітектур і залежно від цілей конкретної архітектури, вузол може бути організацією, організаційним елементом, діяльністю або навіть людиною.

Вузли ідентифікуються відповідною системою або платформою. Вузли також можуть бути описані шляхом ідентифікації організації й місця розташування, пов'язаного 3 вузлом. Організація й місце розташування можуть бути фізичними або умовними залежно від конкретної архітектури.

Інтерфейс системи являє собою спрощене або узагальнене представлення комунікаційного шляху або мережі. Часто пари підключених систем або компонентів системи мають декілька інтерфейсів між ними. Опис системного інтерфейсу відображає всі інтерфейси між системами й/або компонентами системи, що представляють інтерес для архітектора.

На рис. 3 наданий умовний приклад опису внутрішньої структури системного інтерфейсу для реальних систем ОВТ [9].

Локальна мережа (LAN) і глобальна мережа (WAN) $є$ специфікаціями архітектурних моделей i відносяться до технічної архітектури.

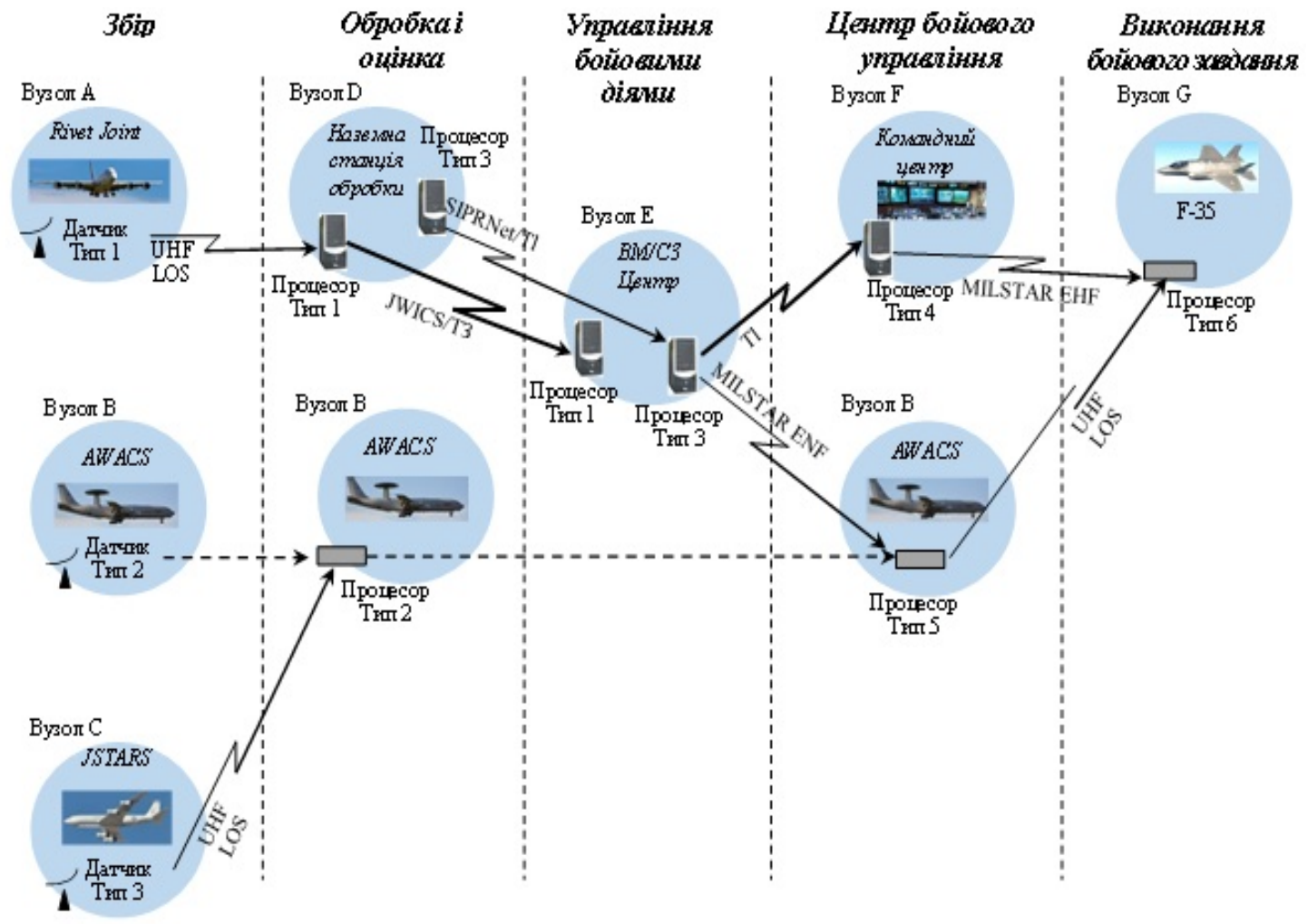

Рис. 3. Умовний приклад опису системного інтерфейсу з урахуванням реальних систем ОВТ Джерело: розроблено авторами за даними [9].

\section{Вплив руйнуючих технологій на зміну парадигми розвитку систем ОВТ.}

Поняття руйнуючих технологій (Disruptive Technology) було введено Clayton M. Christensen [10]. Даний термін найчастіше описується так: руйнуюча технологія - це інновація, яка може повністю витиснути існуючі технології, продукт або послугу. У військовій справі поява руйнуючих технологій завжди призводить до зміни концепції ведення бойових дій, що, у свою чергу, кардинально впливає й на системи ОВТ, які вирішують завдання забезпечення ведення бойових дій.

Розвиток високоточної зброї, в ході якого досягнута точність iï застосування менше 10 м, призвів до того, що точність поразки цілі стала визначатися не можливостями високоточних боєприпасів, а можливостями систем розвідки й управління щодо високоточного визначення координат цілей. Наприклад, висока точність визначення координат цілей практично недосяжна 3 використанням паперових топографічних карт і навіть супутникові системи не завжди забезпечують необхідну точність [5]. Усе це призводить до того, що завдання об'єднання даних 3 різних джерел трансформується в завдання взаємодії різнорідних систем-систем щодо одержання необхідних даних.

У розвитку даного тренду в травні $2007 \mathrm{p}$. MO США випустило документ за назвою: "Strategy for a Net-Centric, Service Oriented DoD Enterprise" [13], у якому була зроблена така заява: “Зміни в мережецентричній стратегії МО США відображують 
визнання того факту, що сервіс-орієнтований підхід може привести до вибухового росту можливостей для наших бійців і осіб, що приймають рішення, i тим самим підвищити оперативну ефективність”. По суті цей документ вирішує завдання розвитку сервісів, які спрощують споживачам використання інформаційних ресурсів і доступ до даних. Бачення МО США полягає в створенні мережецентричного середовища (Net-Centric Environment, NCE), яке усе більше використовує загальні сервіси й сервісорієнтовану архітектуру (SOA) [13].

У 2009 р. вийшла друга версія структури архітектури DoDAF V2+, у якій прямо декларується використання дата-центричної методології [15]. Підкреслюється, що дані $є$ ключовим моментом при розробці архітектури, забезпечуючи інтеграцію й взаємодію між різними архітектурами в рамках різнорідних архітектурних методологій. Основний упор переноситься на методи збору, систематизації й аналізу даних про архітектуру на основі загальної метамоделі даних.

Розвиток дата-центричних технологій приводить до того, що в єдиній мережі різко падає вплив особливостей системної побудови того або іншого озброєння. Аналогічно цьому, у мережі Інтернет без проблем взаємодіють системи, що мають різне програмне забезпечення і різні апаратні платформи.

Використання дата-центричних технологій зажадало єдиного розуміння різних сутностей не тільки фахівцями різних напрямків, але й системами зі штучним інтелектом (Artificial Intelligence, AI), що неминуче призвело до пильного погляду на питання онтології. Виникла проблема: як описувати світ настільки однозначно, щоб навіть комп'ютер міг інтерпретувати ці описи $[2,3]$.

Міжнародна організація з питань специфікації архітектури оборонних підприємств (International Defense Enterprise Architecture Specification, IDEAS) запропонувала формальну онтологію, що сприяє інтероперабельності моделей архітектури [15]. Онтологія IDEAS була покладена в основу метамоделі даних DoDAF, а пізніше була поширена й на інші структури архітектур країн NATO. Якщо в AF C4ISR основним ресурсом була інформація, то в структурі архітектури, заснованої на онтології IDEAS, список використовуваних ресурсів розширений. Це дуже важливий момент. Обмін глобалізується, оперування здійснюється не тільки інформацією, але й іншими ресурсами, наприклад, матеріалами й енергією. Таке розширене представлення потоків супроводжувалося експонентним зростанням кількості пристроїв, що підключаються до мережі. Виникає Інтернет речей (Internet of Things, IoT), який розглядається військовими як руйнуюча технологія [25]. Цілком очевидно, що дана технологія відразу ж одержала свій військовий напрямок - Інтернет війсь- кових пристроїв (Internet of Battlefield Things, IOBT) i здійснила свій вплив на концепцію С3I [22].

Поле бою (battlefield) розширюється на кіберпростір. У квітні 2015 р. ухвалюється кіберстратегія MO США (DoD Cyber Strategy), а в червні 2018 р. об'єднаний комітет начальників штабів (Joint Chiefs of Staff, CJCS) ухвалює “Загальну доктрину для планування, виконання та оцінки операцій в кіберпросторі” [23].

У грудні 2018 р. у МО США вийшов документ за назвою: "DoD Cloud Strategy", у якому акцентується увага на тому, що в сучасній епосі бойових дій поле бою існує не тільки у фізичному, але й у цифровому світі [12]. Хмарні технології $є$ фундаментальним компонентом глобальної інфраструктури й мають вирішальне значення для підтримки технологічної переваги військових США в ході бойових дій у 21 столітті.

Хмарні обчислення - це сервіс, що надає мережеве зберігання даних і обчислювальні ресурси. Він дозволяє користувачам одержувати доступ до інформації з будь-якого місця в будь-який час, ефективно усуваючи необхідність для користувача перебувати в тому ж фізичному просторі, що й апаратне забезпечення, на якому зберігаються дані [12].

Хмарні технології та Інтернет речей призвели до різкого розвитку безпілотних систем і штучного інтелекту (AI). Штучні системи набувають свою власну поведінку, характерну раніше тільки для живих систем. Роль штучного інтелекту настільки зростає, що в МО США розробляється його стратегія "Artificial intelligence strategy" [11].

\section{Дата-центричні системи-систем ОВТ. Загальні поняття й визначення.}

Руйнівні технології, що накопичуються, приводять розвиток ОВТ у чергову точку біфуркації, вихід 3 якої пов'язаний з розвитком теорії дата-центричних операцій (Data-Centric Operations, DCO) і розробкою дата-центричних систем зброї [1] (рис. 4).

Одним $з$ головних принципів дата-центричних операцій стає принцип формування “системосистемного мислення” або, згідно визначення Рассела Аккофа: “модельного мислення” [7].

Автори теорії мережецентричної війни розглядали питання перебудови мислення як одне $з$ основних і навіть увели в концепцію мережецентричних війн (NCW) поняття когнітивної сфери [1].

На наш погляд, більш раціональний інший підхід. Зміна мислення відбувається не в рамках теорії дата-центричних операцій, або якої-небудь іншої теорії, а в рамках переходу суспільства від монорозумної моделі й патерналістської культури до соціокультурних моделей побудови організацій і мультирозумних систем. 


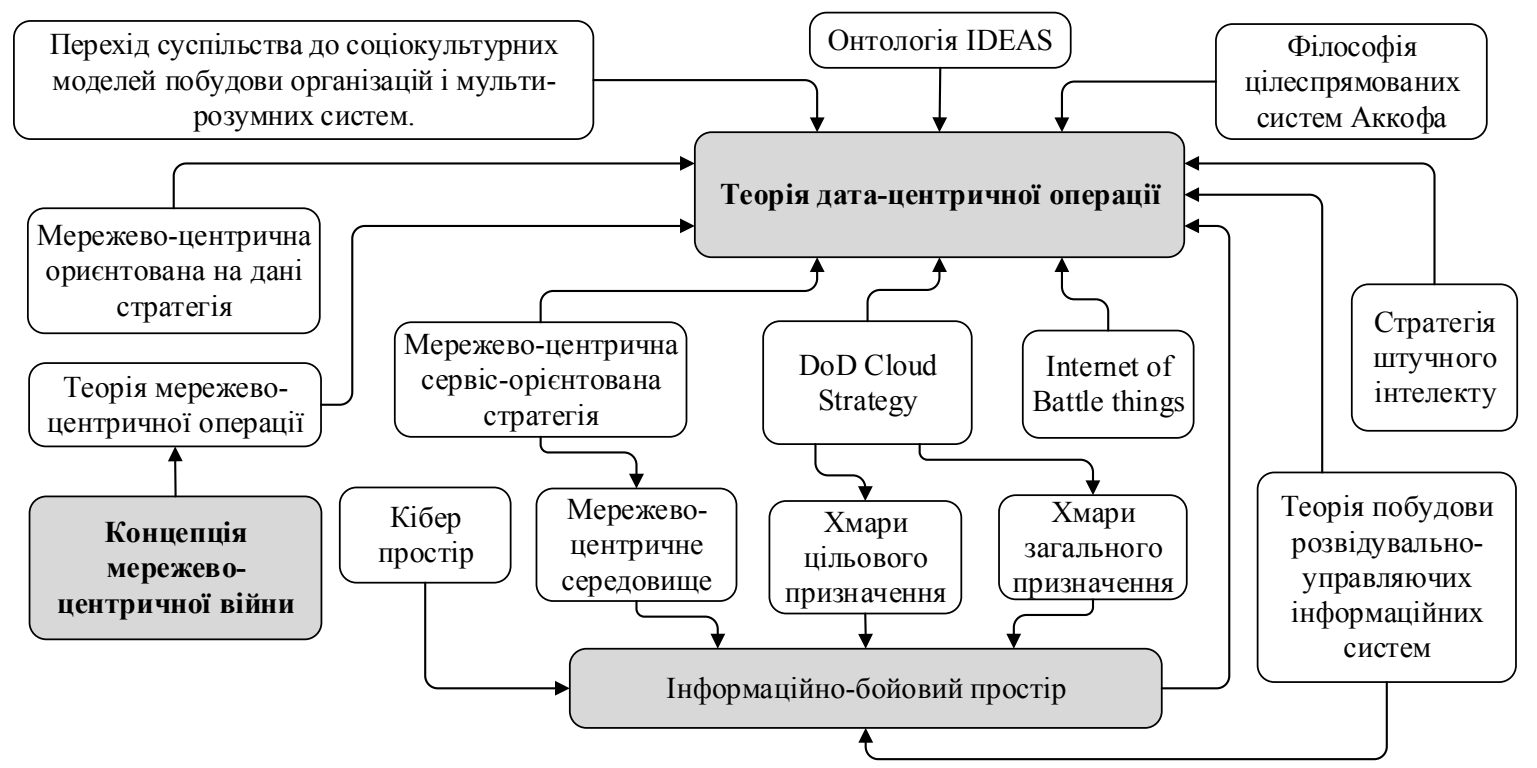

Рис. 4. Інновації та технології, що послужили основою для створення теорії дата-центричних операцій Джерело: розроблено авторами.

У рамках монорозумної моделі видатний промисловець Альфред Стоун запропонував свою модель управління, яка $з$ невеликими варіаціями дотепер становить основу навчальних програм ділового адміністрування в таких університетах як Гарвард, Стенфорд і Массачусетський технологічний інститут [14].

Із практичної точки зору, дана модель побудована на двох концепціях: дивізіональної структури (рис. 5) і методу планування й підготовки [14].

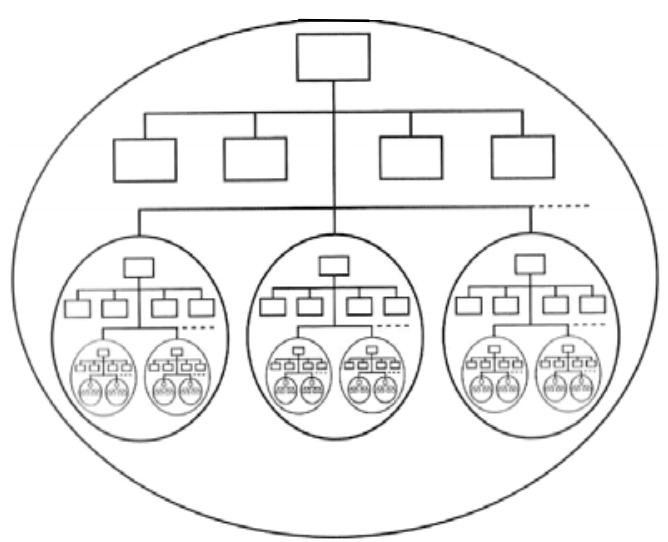

Рис. 5. Дивізіональна структура

Джерело: розроблено авторами за даними [14].

Корпоративна організація в іiі найпростішому вигляді розділена на дві окремі частини: “головний офіс" - керуюча ланка з підрозділами забезпечення й “операційні одиниці”.

Кожна операційна одиниця, будучи досить автономною, являє собою зменшену модель корпорації, але зосереджена на вирішенні обмеженого кола питань у рамках поставленого перед нею завдання.
Фактично ця ж модель із невеликими варіаціями реалізується при побудові систем ОВТ і в організаційно-штатній структурі частин і підрозділів.

Сучасні системи озброєння за своєю суттю $є$ багатофункціональними й призначені для функціонування в широкому діапазоні умов зовнішнього середовища. Виникає питання вибору шляхів їх розвитку, який у цей час звівся до двох напрямків: багатоструктурні системи й системи-систем (рис. 6) $[6 ; 18 ; 24]$.

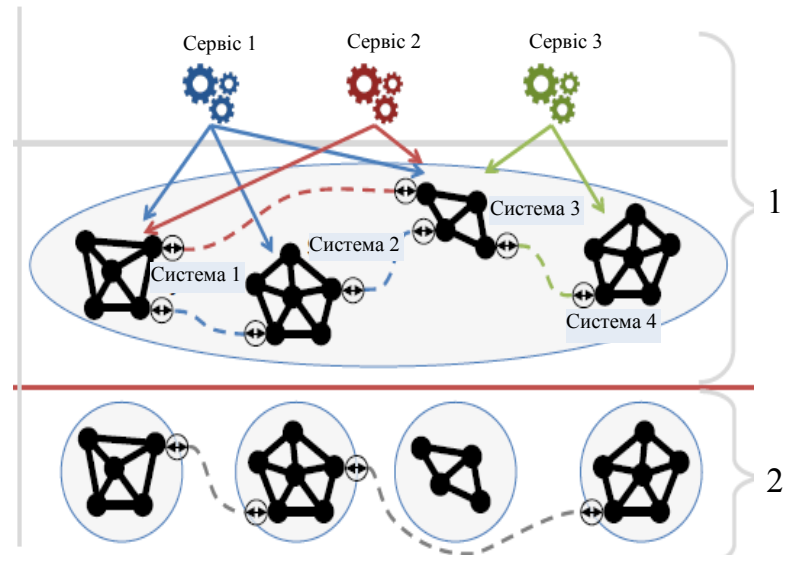

o

- використання систем для розробки сервісів - інтерфейси

Рис. 6. Складні системи:

1 - системи-систем;

2 - багатоструктурні системи

Джерело: розроблено авторами за даними [18].

Багатоструктурні системи розглядаються як системи ОВТ, які в сучасних умовах ведення бойових дій наділяються здатністю перебудовувати свою структуру. Відповідно в рамках “класичного” сис- 
темного підходу структурно різняться: системи, підсистеми й елементи. Уводиться поняття структурної динаміки “як процесу зміни в часі структури складних багатоструктурних систем (СБСС) ... який цілеспрямовано управляється" [6]. Як приклад таких СБСС там же наводитися структурно-єдина система протиповітряної оборони (ППО), яка складається 3 підсистем: пораження й подавлення засобів повітряного нападу; розвідувально-інформаційної; управління й зв'язку; забезпечення. Кожна підсистема, будучи досить автономною, проте, зосереджена на вирішенні обмеженого кола питань у рамках поставленого перед нею завдання, тому в СБСС підсистеми “не вміють” домовлятися між собою й “навчити” їх цьому неможливо. Поліпшення зв'язків такої СБСС за рахунок впровадження мереж не робить і1і мережево-ємною, а тільки поліпшує можливості інформаційної взаємодії. Оптимізація структури такої системи пов'язана 3 наявністю первісної надмірності ії елементів і можливістю централізованого (моноразумного) управління. Даний підхід цілком застосовуваний для існуючої сьогодні структури військових формувань, і при вирішенні цілого ряду завдань може розглядатися як пріоритетний. Розглянемо іншу парадигму - “систем, що складаються iз систем”. Поняття підсистем зникло із сучасного трактування загальної теорії систем, що закріплене відповідними стандартами системної інженерії [8].

Система-систем (SoS) - це сукупність або організація систем, результатом якої $є$ інтеграція незалежних і придатних для використання (useful) cистем у більшу систему, що володіє унікальними можливостями (емерджентними властивостями). Так як системи незалежні, то в рамках $\mathrm{SoS}$ треба “навчити їх співробітничати”. При цьому зовсім необов'язково, щоб системи, що входять у $\mathrm{SoS}$, мали надмірність елементів для перебудови структури.

Надмірність елементів має інший клас систем: сімейство систем (family of systems, FoS) - це набір або комбінація незалежних (не взаємозалежних) систем, які надають схожі можливості за допомогою різних підходів для досягнення схожих або взаємодоповнюючих ефектів [24].

Розглянуті вище підсистеми системи ППО можуть розглядатися як сімейство систем (FoS).

Окремі системи можуть бути організовані або об’єднані в сімейство систем різними способами для забезпечення реалізації різних можливостей. Поєднання систем може бути адаптоване для забезпечення бажаних можливостей залежно від ситуації.

Системо-системний підхід особливо важливий при веденні бойових дій міжвидовим угрупованням військ (сил), де по суті або відсутня, або часто порушується під час бою дивізіональна структура (саме тому автори $\mathrm{NCW}$, визнаючи обмеженість “самосинхронізації” приділяли їй стільки уваги).
Слід зазначити, що на початковому етапі системи-систем ОВТ створювалися шляхом інтеграції незалежних раніше систем ОВТ у структури, що здобувають нові емерджентні властивості, що й забезпечувало підвищення їх бойової моці. Об'єднання систем здійснювалося на базі розроблених у комерційному секторі мережевих технологій. Такі системи-систем, незважаючи на використання мереж, все-таки слід віднести до програмо-ємних (software-intensive) систем. Сучасні системи-систем ОВТ відрізняються [20; 24]:

- оперативною незалежністю складових їхніх систем, тобто кожна система зі складу SoS може працювати незалежно й здатна досягати своїх власних цілей під час відсутності інших складових систем;

- управлінська незалежність складових їхніх систем, тобто системи зі складу $\mathrm{SoS}$ управляються незалежно й можуть бути додані або вилучені з SoS;

- еволюційна незалежність складових їхніх систем, у яких функції й цілі додаються, видаляються або змінюються за необхідністю;

- виникаючою поведінкою, яка не може бути локалізована в якій-небудь системі, що входить до складу SoS;

- географічним розподілом систем, що входять до іiі складу.

- зміна структури впродовж життєвого циклу.

У NATO виділено чотири типи SoS, що відрізняються ступенем їх автономності [20; 24]:

1) Системи з централізованим управлінням або інакше директивні (directed) SoS, які створюються й управляються для виконання певних цілей, а складові системи підпорядковуються SoS (рис. 7).

$\mathrm{Y}$ директивній SoS оператори O2 i O3 приймають управління від O1 з погляду вимог, специфікації й роботи систем, якими вони володіють (О2 володіє системами S2 i S3; О3 володіє системою S4). Цей тип SoS жорстко контролюється центральним органом управління (O1). Складові системи зберігають здатність працювати незалежно, але їх нормальний режим роботи підпорядкований центральній меті, яка управляється;

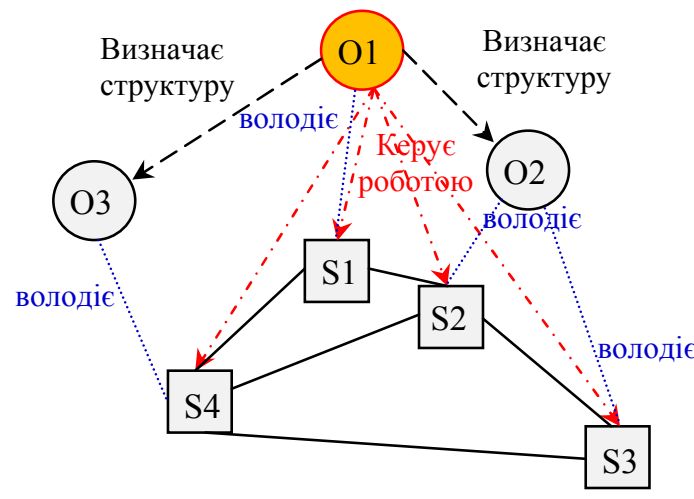

Рис. 7. Директивні системи-систем Джерело: розроблено авторами за даними [20]. 
2) Взаємодіючі (напівавтономні) або визнані (acknowledged) системи, у яких є визнані цілі, визначений керівник і ресурси для SoS. Однак складові системи зберігають свою незалежну власність, цілі, фінансування, підходи до розвитку та підтримки. Зміни в системах грунтуються на угодах про співпрацю між SoS та іiі складовими системами (рис. 8).

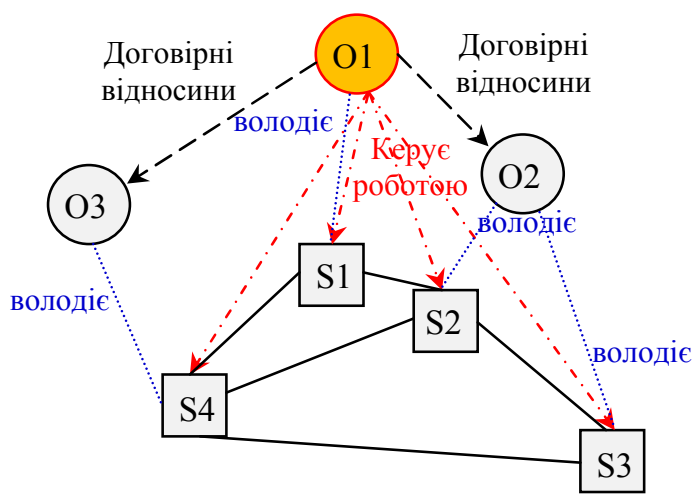

Рис. 8. Підтверджені або визнані SoS

Джерело: розроблено авторами за даними [20].

У взаємодіючих SoS, O1 керує вибором систем та їх функціонуванням; О2 і О3 мають договірні відносини з О1. У цьому випадку центральний орган управління (O1), здійснює безпосереднє управління (Government), визначає вимоги SoS-рівня, але меншою мірою контролює складені системи, що належать іншим суб'єктам $\mathrm{SoS}$ - O2 і O3 (S2, S3, S4) i має більшою мірою покладатися на вплив. Однак, складові системи зберігають свою незалежну власність, цілі, підходи до фінансування, розвитку й підтримки. Зміни в системах засновані на угодах про співробітництво між SoS і складовими системами. Приклад такого типу $\mathrm{SoS}$ - “розумне місто”.

3) Колаборативні, або співпрацюючі (collaborative) системи взаємодіють більш-менш добровільно “агностичним" чином для досягнення погоджених загальних цілей SoS (рис. 9).

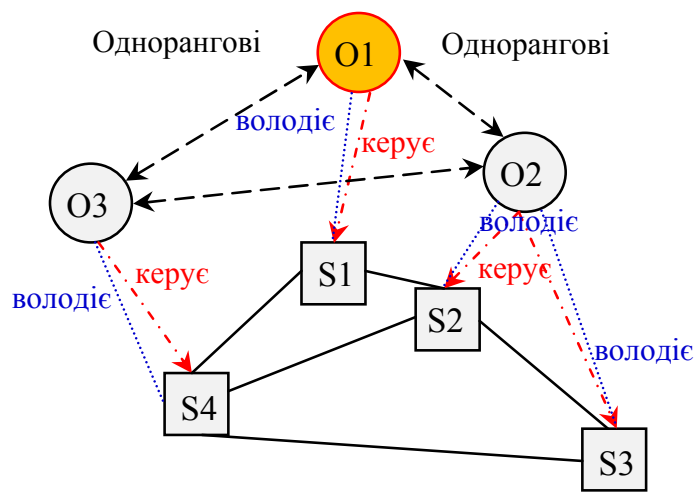

Рис. 9. Колаборативні системи-систем Джерело: розроблено авторами за даними [20].
У таких системах існує взаємна згода про співробітництво, звичайно обумовлена договорами або угодами в тій або іншій формі, але немає загальної управляючої організації, яка визначає вимоги SoS. Власники систем (O1, O2, О3) управляють своїми власними системами й співробітничають із іншими для реалізації деякої загальної вигоди. Цей клас систем найкраще підходить для тих $\mathrm{SoS}$ де складові системи “належать” різним військовим підрозділам, усі з яких перебувають у рівних позиціях підпорядкованості, і немає домінуючої організації. Організація взаємодії між окремими зенітними ракетними підрозділами в рамках системи зенітного ракетного прикриття являє приклад цього типу SoS.

4) віртуальні системи не впливають одна на одну явно, немає центрального органа управління й централізовано погодженої мети для SoS (рис. 10).

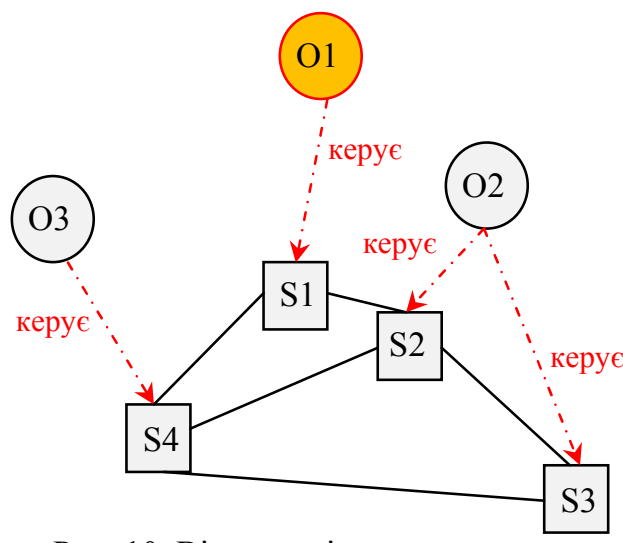

Рис. 10. Віртуальні системи-систем

Джерело: розроблено авторами за даними ґ201.

У віртуальній $\mathrm{SoS}$ власники (O1, O2, O3) одержують доступ до інших систем через мережу, щоб реалізувати індивідуально необхідні можливості, хоча при цьому може зберігатися високий рівень емерджентної поведінки. Немає загальної мети, немає централізованого управління й взаємодії за визнаними процедурами або стандартами, діють індивідуальні угоди між парами систем. Виникає великомасштабна поведінка, але цей тип SoS покладається не на механізми управління системами, а на механізми впливу на поведінку - “піднаглядність” (organizational decentralized governance) [1].

У дата-центричних системах-систем (рис. 11) реалізація цілеспрямованої мультирозумної моделі дозволяє розглядати наведені ступені автономності не як властивості окремих SoS, а як способи взаємодії (поведінки) систем зі складу $\mathrm{SoS}$ [1]. Окремі одиниці зброї (системи), що знаходяться в мережевому оточенні DWSoS розглядаються як ресурс, який може використовуватися для реконфігурації структури цільових систем (кластер-систем), що забезпечить реалізацію необхідних можливостей на окремих часових фазах. 


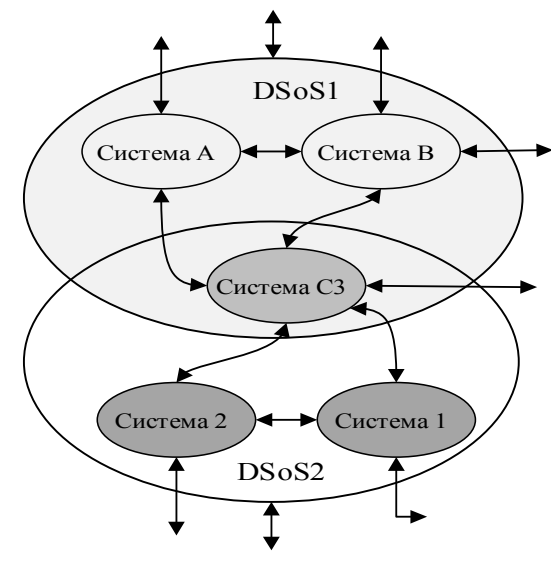

Рис. 11. Дата-центричні системи-систем Джерело: розроблено авторами за даними [1].

Хрональна локалізація системи визначається тим, що досягнення мети може бути здійснене в декілька етапів, на яких завдання системи, а значить i набір функцій системи й необхідний для реалізації цих функцій набір елементів можуть мінятися. При такому підході структура DWSoS визначається траєкторією ii субституціонального руху, сукупністю стійких станів, зв'язків між ними в процесі функціонування системи щодо досягнення поставленої перед нею мети [4]. Субституціоний рух системи ("substitucio" (лат.) означає “заміна") - це процес заміни iї елементів на одному або декількох рівнях іiі ієрархічної будови. Середовищем для датацентричних систем ОВТ служить мережа. При “системоцентричній” точці зору на вхід “нерухомої” системи надходять потоки елементів (item flow), відбувається заміна елементів, тобто плин субституціонного часу системи [4]. Дата-центрична системасистем ОВТ може бути визначена як відособлений просторово, обмежений хронально, такий що змінюється в часі, і відносно самодостатній фрагмент світу i, в той же час, як організована цілісність, що складається із частин, об'єднана різного роду відносинами, яка має загальну особливу якість (емерджентність), не рівну сумі властивостей частин, що входять у це ціле.

Дата-центричні системи-систем ОВТ наділяються здатністю синтезувати й реконфігурувати (перестворювати) свою структуру. Однією $з$ найважливіших відмінностей дата-центричних системсистем OBT від C4ISR $є$ те, що оперування здійснюється не тільки інформацією, але й ресурсами.

Модель інформаційного обміну, характерна для C4ISR, міняється на ресурсну-потокову модель датацентричної операції, реалізованої дата-центричною системою-систем ОВТ (рис. 12).

Дата-центрическа операція, яка здійснюється 3 використанням дата-центричних систем, являє собою взаємопов'язані процеси збирання кластер-системи (цільової системи) і використання кластер-системи відповідно до ії цільового призначення.

Синтез (зборка) дата-центричних кластерсистем, відповідно до концепції дата-центричних операцій (DCO), може здійснюватися в рамках трьох основних парадигм:

- структурної динаміки багатоструктурних систем (multi structural system of systems, MS SoS);

- мережецентричної взаємодії SoS;

- дата-центричної взаємодії.

Прикладом багатоструктурної системи $є$ розглянута вище система ППО. Кожна з ії підсистем подібна “процедурі” у програмуванні. Виклик процедури в програмі здійснюється для вирішення конкретного завдання. Виклики “систем-процедур” організовуються за допомогою центрального “оброблювача подій”, аналогом якого в системі ППО виступає командний пункт.

Мережецентрична взаємодія систем-систем припускає, що між окремими об'єктами (модулями), які мають достатній ступень автономності, організовується з використанням мережевих технологій взаємодія на рівні інформаційного обміну. Як аналог в об'єктно-орієнтованому програмуванні об'єкти взаємодіють шляхом обміну повідомленнями.

Найбільш розвиненим варіантом мережецентричних архітектур виступає BMC4I - мережева розподілена архітектура (Netted-Distributed Architecture with Plug-and- Fight) зенітного ракетного комплексу MEADS. У рамках ЗРК як системи-систем, системи що його складають виступають як вузли мережі MEADS, що дозволяє динамічно змінювати структуру системи й використовувати зовнішні джерела інформації.

Слід зазначити, що архітектура BMC4I маючи механізм динамічного зв'язування систем у складі системи-систем може розглядатися як перехідна між мережецентричною і дата-центричною. Разом $з$ тим, системи, що перебувають у вузлах мережі мають модульну структуру - мають неподілюваний набір атрибутів/властивостей.

Наведемо досить грубе, але таке, що відображує суть речей, порівняння: мікроскоп може бути використаний тільки відповідно до свого цільового призначення, і навіть в умовах надзвичайної потреби не може бути застосований як молоток. У системах озброєння це приводить до їхньої вузької спеціалізації.

Спроби створення універсальних систем зброї в рамках структурної й мережецентричної парадигм, як правило закінчувалися невдачею. Такі системи OBТ або мали значну вартість, або були недостатньо ефективними. 


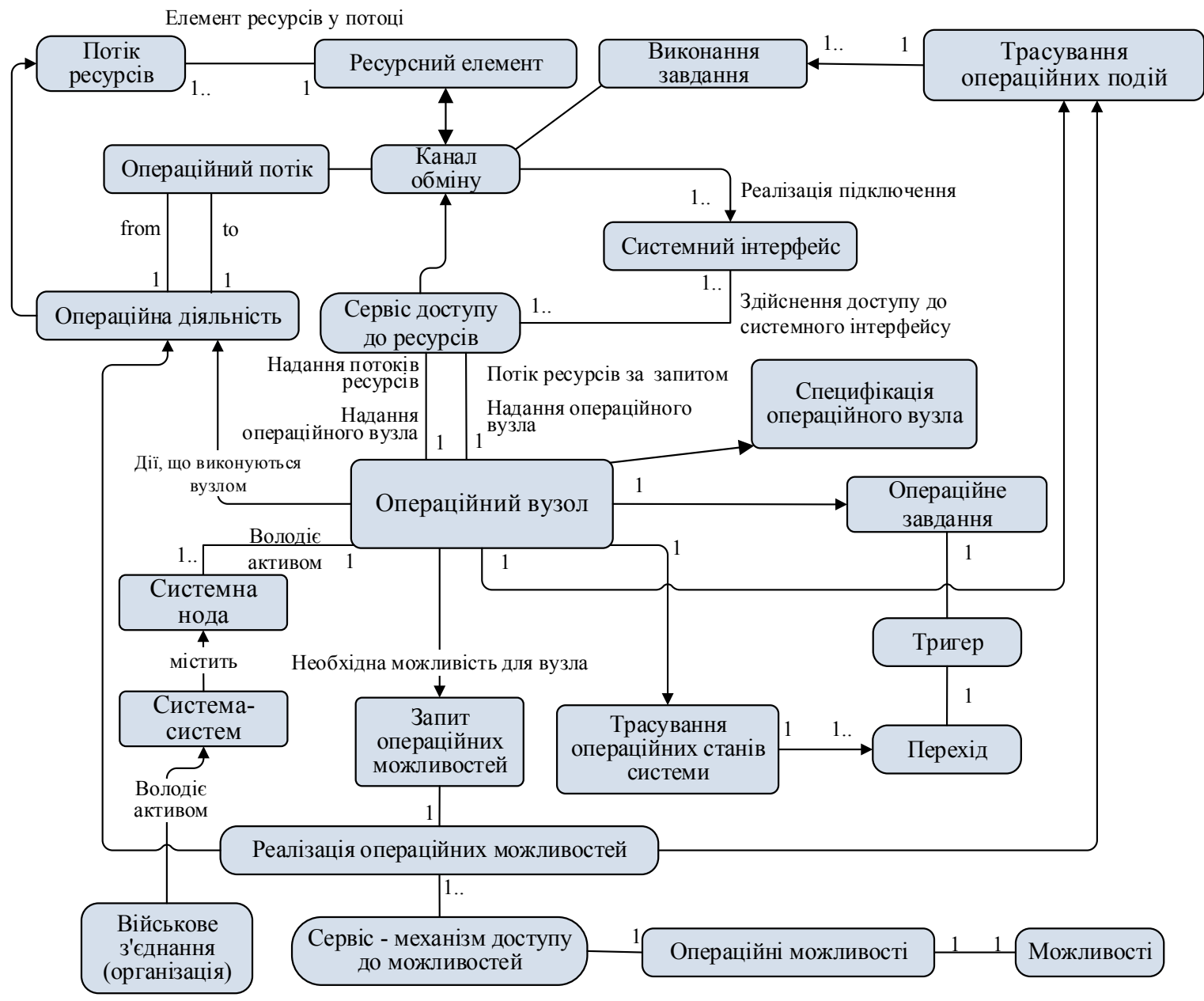

Рис. 12. Ресурсна-потокова модель дата-центричної операції, що реалізується дата-центричною системою систем

Джерело: розроблено авторами за даними [15].

Дата-центрична взаємодія припускає синтез кластер-системи на базі використання сімействсистем (FoS), що вирішують завдання, які відносяться до різних класів. Такий синтез систем-систем має багато загальних рис із аспектно-орієнтованим підходом (aspect-oriented software development, AOSD) у програмуванні [21]. При цьому синтез іде в рамках ланцюжка: агрегації - мережі - системи. На відміну від аспектно-орієнтованого підходу за функціональними аспектами розрізняються не системи, а агрегації.

Траєкторії субституціонального руху системи можуть бути представлені у вигляді типізованих трас, що розбивають (трасирують) на окремі ділянки згідно виконуваних функціональних завдань. На ділянках можливе розрізнення (саме розрізнення, а не поділ як у багатоструктурних системах) окремих систем за функціональними ознаками, але не за ознаками апаратної реалізації. Наприклад, у датацентричній системі ППО як окремі можуть розрізнятися системи управління й розвідки, тобто розбиватися на функціональні класи: джерела інформації й пристрої управління. Однак поділ на окремі системи зенітного ракетного прикриття й винищувально-авіаційного прикриття, тобто поділ згідно апаратної ознаки вже недоцільний.

\section{Висновки}

Сьогоднішнє бачення датацентричної операції суттєво відрізняється від того, що від самого початку вкладалося в концепцію мережецентричної війни.

Сукупність онтології IDEAS, SOA і хмарної архітектури, підтримані сучасним розвитком безпілотних систем, AI, IOBT і комунікаційних систем створюють ту руйнуючу технологію, яка повинна докорінно змінити існуючі підходи до побудови систем ОВТ.

Якщо технічне втілення теорії мережецентричної війни шукалося в напрямку розробки C4ISR систем-систем, то теорія дата-центричної операції передбачає створення нового класу систем - датацентричної системи-систем ОВТ.

Концепція побудови архітектури датацентричних $\mathrm{SoS}$ передбачає, що DCW-системи на- 
діляються здатністю синтезувати й реконфігурувати (перестворювати) свою структуру. Однією 3 найважливіших відмінностей дата-центричних $\mathrm{SoS}$ від C4ISR-систем $є$ те, що оперування здійснюється не тільки інформацією, але й ресурсами.
Модель інформаційного обміну, характерна для C4ISR, міняється на ресурсну-потокову модель датацентричної операції.

\section{Список літератури}

1. Скорик А.Б. Еволюційний розвиток концепції мережецентричних війн. Системно-концептуальні основи теорії датацентричних операцій / А.Б. Скорик, С.П. Ярош // Системи озброєння і військова техніка. - 2020. - № 4(64). - С. 107-119. https://doi.org/10.30748/soivt.2020.64.14.

2. Левенчук А. Системно инженерное мышление [Електронний ресурс] / А. Левенчук. - 2015. - С. 1-3. - Режим доступу: http://techinvestlab.ru/files/systems_engineering thinking/systems_engineering thinking_2015.pdf.

3. Левенчук А. Системное мышление [Електронний ресурс] / А. Левенчук. - 2020. - Режим доступу: https://ridero.ru/books/sistemnoe_myshlenie/freeText.

4. Принципи розробки перспективного ЗРК з використанням NSW-концепції і еволюційно-технологічного підходу / А.Б. Скорик, О.Д. Флоров, О.М. Доска, Ю.В. Коробков // Системи озброєння і військова техніка. - 2009. - № 3(19). C. 28-36.

5. Аналіз особливостей побудови і застосування перспективних систем управління високоточною зброєю / А.Б. Скорик, О.Д. Флоров, С.В. Моргун, Д.В. Молчанов, О.В. Гречка, С.М. Шепелевич // Наука і техніка Повітряних Сил Збройних Сил України. - 2018. - № 4(33). - С. 43-51. https://doi.org/10.30748/nitps.2018.33.06.

6. Управління структурною динамікою складних систем військового призначення у оперативно-тактичній обстановці, що динамічно змінюється / Д.А. Гриб, Б.О. Демідов, О.В. Довбня та ін. // Наука і техніка Повітряних Сил Збройних Сил України. - 2019. - № 2(35). - C.16-26. https://doi.org/10.30748/nitps.2019.35.02.

7. Ackoff R. Redesigning the Future: A Systems Approach to Societal Problems / R. Ackoff. - John Wiley \& Sons: New York, 1974. $-240 \mathrm{p}$.

8. ISO/IEC/IEEE 15288, IEEE 15288.1, and IEEE 15288.2. Best practices for using systems engineering standards on contracts for Department of Defense Acquisition Programs [Electronic resource] / Office of the Under Secretary of Defense for Acquisition \& Sustainment. - Available at: https://www.acq.osd.mil/.

9. C4ISR Architecture Framework Version 2.0 / C4ISR Architecture Working Group // Office of the Assistant Secretary of Defense for Command, Control, Communications and Intelligence. - Washington: D.C., November, 1997. - Available at: https://www.afcea.org/education/courses/archfwk2.pdf.

10. Clayton M. The innovator's dilemma: when new technologies cause great firms to fail / M. Clayton. - Harvard: Harvard Business Review Press, 2016. - 288 p.

11. Danielle C. The Department of Defense Posture for Artificial Intelligence. Assessment and Recommendations / C. Danielle. - Santa Monica: RAND Corporation, 2019. - $187 \mathrm{p}$.

12. Memorandum. DoD Cloud Strategy [Electronic resource] / Department of Defense. - Washington: D.C., 2018. - Available at: https://media.defense.gov/2019/Feb/04/2002085866/-1/-1/1/DOD-CLOUD-STRATEGY.PDF.

13. Memorandum. DoD Net-Centric Services Strategy [Electronic resource] / Department of Defense. - Washington: D.C., 2007. - Available at: https://www.hsdl.org/?abstract\&did=485988.

14. Gharajedaghi J. Systems Thinking: Managing Chaos and Complexity: A Platform for Designing Business Architecture / J. Gharajedaghi. - Oxford: Elsevier, 2011. - 376 p

15. Giachetti R. Evaluation of the DoDAF Meta-model's Support of Systems Engineering / R. Giachetti // Procedia Computer Science. - 2015. - № 61. - P. 254-260. https://doi.org/10.1016/j.procs.2015.09.208.

16. Hause M. Technology Update on the Unified Architecture Framework / M. Hause // 26-th Annual INCOSE International Symposium. - Edinburgh, 18-21 July 2016. https://doi.org/10.1002/j.2334-5837.2016.00217.x.

17. Levis A. C4ISR architectures: I. Developing a process for C4ISR architecture design / A. Levis, L. Wagenhals // Systems Engineering. - 2000. - № 3(4). - P. 225-247. · https://doi.org/10.1002/1520-6858 (2000)3:43.0.CO;2-\#.

18. Eichmann C. Model-based Development of a System of Systems Using Unified Architecture Framework: A Case Study / C. Eichmann, S. Melzer, R. God [Electronic resource] // 2019 IEEE International Systems Conference. - Orlando: 8-11 April 2019. - Available at: http://toc.proceedings.com/49573webtoc.pdf.

19. NATO architecture framework [Electronic resource] / Architecture Capability Team Consultation. - Command \& Control Board, 2018. - Available at: https://www.nato.int/nato_static_fl2014/assets/pdf/pdf_2018_08/20180801_180801-ac322d 20180002 naf final.pdf.

20. Ncube C. On Systems of Systems Engineering: a Requirements Engineering Perspective and Research Agenda / C. Ncube, S. Ling Lim // IEEE 26-th International Requirements Engineering Conference. - Banff, Alberta, 20-24 August 2018. - P. 112-123. https://doi.org/ 10.1109/RE.2018.00021.

21. Owens W. The Emerging U.S. System-of-Systems [Electronic resource] / W. Owens // Strategic Forum. Institute for National Strategic. -1996. - № 3. - C. 1-6. - Available at: https://apps.dtic.mil/dtic/tr/fulltext/u2/a394313.pdf.

22. Russell S. The Internet of Battlefield Things: The Next Generation of Command, Control, Communications and Intelligence Decision-Making / S. Russell, T. Abdelzaher // IEEE Military Communications Conference. - Los Angeles, 29-31 October 2018. https://doi.org/10.1109/milcom.2018.8599853.

23. Scott K. Cyberspace Operations / K. Scott. - United States: Joint Chiefs of Staff, 2018. - 25 p. - Available at: https://www.jcs.mil/Portals/36/Documents/Doctrine/pubs/jp3_12.pdf.

24. Henshaw M. The Systems of Systems Engineering [Electronic resource] / M. Henshaw, C. Siemieniuch, M. Sinclair // International Conference on System Science and Engineering. - Budapest, 4-6 July 2013. - Available at: https://www.researchgate.net/publication/261280481_Systems_of_Systems_Engineering_A_research_imperative. 
25. Tonin M. The internet of things: promises and perils of a disruptive technology [Electronic resource] / M. Tonin // Science and technology committee. - 2017. - 18 p. - Available at: https://www.nato-pa.int/viewfile?filename $=/$ sites/default/files/2017-11/2017\%20-\%20175\%20STCTTS $\% 2017 \% 20 \mathrm{E} \% 20 \mathrm{bis} \% 20$ -

\%20INTERNET\%20OF\%20THINGS.pdf.

\section{Відомості про авторів:}

Скорик Анатолій Борисович кандидат технічних наук доцент доцент кафедри

Харківського національного університету

Повітряних Сил ім. І. Кожедуба,

Харків, Україна,

https://orcid.org/0000-0002-4327-8796

\author{
Ярош Сергій Петрович \\ доктор військових наук професор \\ професор кафедри \\ Харківського національного університету \\ Повітряних Сил ім. І. Кожедуба, \\ Харків, Україна, \\ https://orcid.org/0000-0002-5208-9372
}

\author{
Меленті Дмитро Олександрович \\ викладач \\ Харківського національного \\ університету Повітряних Сил ім. І. Кожедуба, \\ Харків, Україна \\ https://orcid.org/0000-0002-4929-2193
}

\author{
Information about the authors: \\ Anatolii Skoryk \\ Candidate of Technical Sciences Associate Professor \\ Associate Professor \\ of Ivan Kozhedub Kharkiv \\ National Air Force University, \\ Kharkiv, Ukraine \\ https://orcid.org/0000-0002-4327-8796
}

\author{
Serhii Yarosh \\ Doctor of Military Sciences Professor \\ Professor of Department \\ of Ivan Kozhedub Kharkiv \\ National Air Force University, \\ Kharkiv, Ukraine \\ https://orcid.org/0000-0002-5208-9372
}

\author{
Dmytro Melenti \\ Instructor \\ of Ivan Kozhedub \\ Kharkiv National Air Force University, \\ Kharkiv, Ukraine \\ https://orcid.org/0000-0002-4929-2193
}

\title{
ВЛИЯНИЕ РАЗРУШАЮЩИХ ТЕХНОЛОГИЙ НА РАЗВИТИЕ АРХИТЕКТУРЫ C4ISR СИСТЕМ. КОНЦЕПТУАЛЬНЫЕ ОСНОВЫ АРХИТЕКТУРЫ ДАТА-ЦЕНТРИЧЕСКОЙ СИСТЕМЫ-СИСТЕМ
}

\author{
А.Б. Скорик, С.П. Ярош, Д.А. Меленти
}

В статье проанализированы особенности операционной, системной и технической архитектуры систем C4ISR. Рассмотрена модель информационного обмена C4ISR. Как разрушительные рассматриваются следуюшие технологии и инновации: сервис-ориентированная архитектура, системы с искусственным интеллектом, облачные вычисления и интернет вещей для боевых действий; онтология IDEAS, расширение единого информационно-боевого пространства на киберпространство, тактические и стратегические облака. Делается вывод о возникновении новой точки бифуркаичи выход из которой связан с развитием теории дата-центрических операций и разработкой дата-центрических систем-систем. Рассмотрена общая концепция архитектуры дата-центрической системы-систем, предложена ресурсная-потоковая модель архитектуры дата-центрических систем-систем.

Ключевые слова: дата-центрическая операция, дата-центрическая система-систем, сетецентрическая война, 4D-екстениионализм, самосинхронизачия, сетеемкие системы, структура архитектуры, C4ISR.

\section{IMPACT OF DISRUPTIVE TECHNOLOGIES ON THE DEVELOPMENT OF C4ISR SYSTEMS. CONCEPTUAL FRAMEWORK OF DATA-CENTRIC SYSTEM OF SYSTEMS ARCHITECTURE}

\author{
A. Skoryk, S. Yarosh, D. Melenti
}

The article briefly analyzes the operating, system and technical architecture of the C4ISR systems. The model of C4ISR information exchange is considered and an example of the description of the system interface, taking into account the use of real weapons and military equipment systems is given. The following technologies and innovations are considered as destructive: service-oriented architecture, systems with artificial intelligence, cloud computing and Internet of battle things; IDEAS ontology, expansion of a single information and combat space into cyberspace, tactical and strategic clouds. Artificial systems are acquiring their own behavior, previously characteristic only for living systems. The conclusion is made about the emergence of a new bifurcation point, which is associated with the development of the theory of data-centric operations and the design of datacentric weapons systems. General concepts are considered, and a resource-streaming model of data-centric weapon systems is defined and proposed. The property of system-system integrity is defined by unambiguous isolation of a subset of system elements from network elements that have spatial and chronological localization. Complication of system-systems organization is carried out in frames of chain: aggregations - networks - systems. The conclusion is made about the presence of hardware redundancy in modern weapon systems and the possibility of its use within the framework of system-systems as a network resource, the management of which will allow to obtain additional operational capabilities and increase the efficiency of combat operations.

Keywords: data-centric operation, network-centric warfare, 4D-extensionalism, systems of systems, ontological model, self-synchronization, architectural framework, C4ISR, Internet of battle things, AF ADS. 